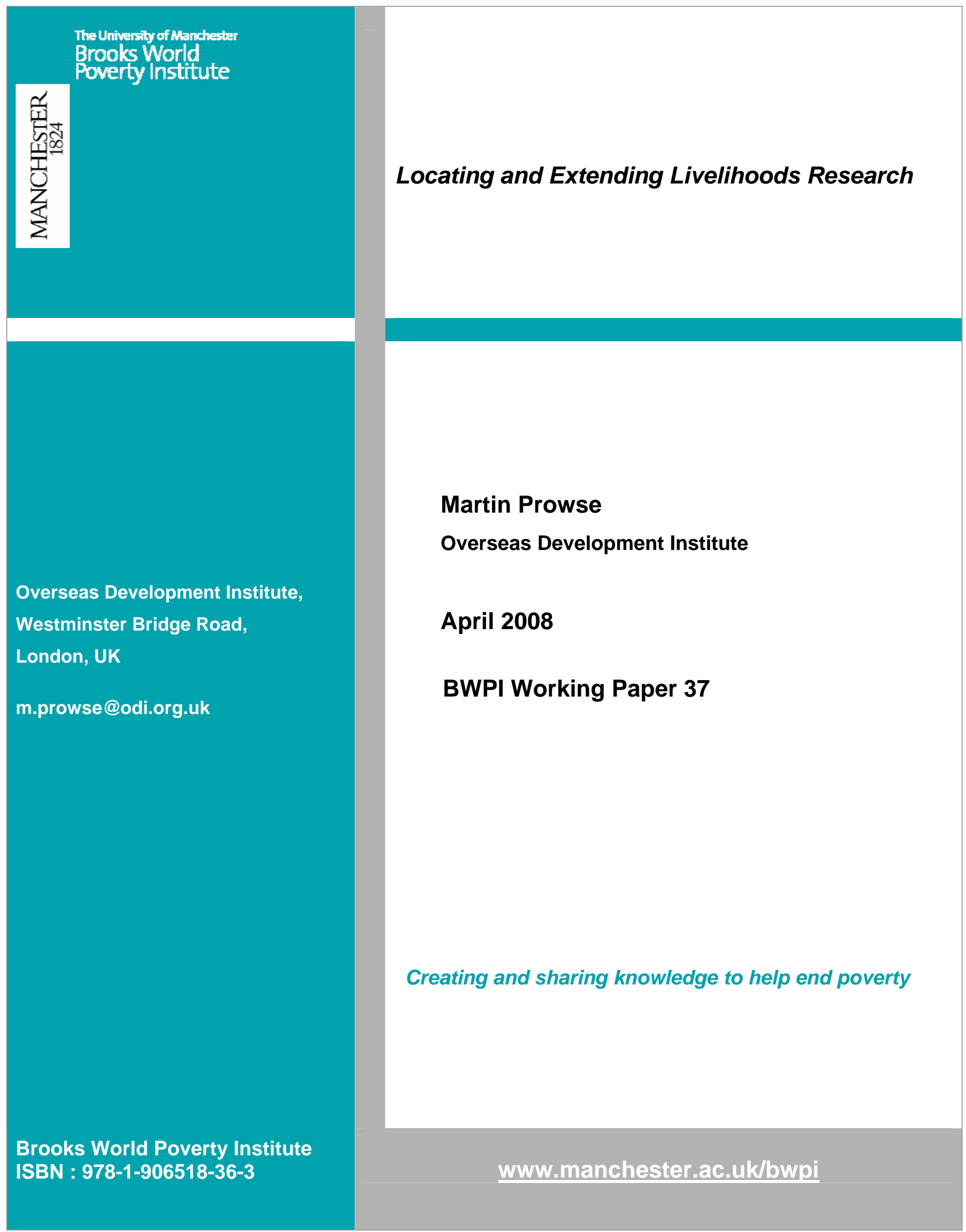




\begin{abstract}
Much poverty and development research is not explicit about its methodology or philosophical foundations. Based on the extended case method of Burawoy and the epistemological standpoint of critical realism, this paper discusses a methodological approach for reflexive inductive livelihoods research that overcomes the unproductive social science dualism of positivism and social constructivism. The approach is linked to a conceptual framework and a menu of research methods that can be sequenced and iterated in light of research questions.
\end{abstract}

Keywords: livelihoods, methodology, ontology, epistemology, cross-disciplinary research, research methods, poverty.

Martin Prowse is a research officer at the Overseas Development Institute, London.

Email: m.prowse@odi.org.uk 


\section{Locating and extending livelihoods research}

Stating explicitly how social research is organised, and where in the broad spectrum of social scientific standpoints it claims to reside, are fundamental elements of rigorous and ethical research. This is particularly the case for development studies compared to other social science disciplines. Not only because of the relative youth of the subject as a distinct (albeit contested) disciplinary area (Kothari, 2005), but also because of the seemingly everexpanding remit of what constitutes 'development' research, and the lack of theoretical depth which this increased width has engendered (Bernstein, 2005).

Instead of engaging with methodological or epistemological debates, much poverty and development research presents a smooth ex post account of research methods (often airbrushing dead ends and false starts). This tendency may be exacerbated by publishing protocols regarding the length, structure, format and style of outputs. Whilst such 'disciplining' serves a purpose (for it contributes to an easily accessible text for the reader to follow), relegating methodology and epistemology entirely to the recycle bin can only be detrimental for the research process, and for the relevance of findings.

This paper argues there are substantial benefits in adhering to a clear methodology and being explicit about the epistemological standpoint when conducting research. Doing so can help to explain how research findings are generated, how robust findings are, how findings can or cannot be extrapolated and generalised, and how they may or may not be able to inform policy.

To be able to make these arguments, this paper discusses the philosophical underpinnings on which much social research is explicitly or implicitly based. What is at issue here is the relationship between a researcher and the external world. There are two key parts to this question (Danermark et al, 2002; Santos, 2005). The first is 'what is the nature and constitution of objects in the external world?' often referred to as ontology. The second part of the question is 'how can we as researchers gain knowledge about the external world?', often referred to as epistemology. These meta-theoretical questions and predicaments are not subject to definitive closure. The particular choices that social researchers make regarding their ontological and epistemological position relate, first, to their subjective values, beliefs and world view (Conticini, 2005; Punch, 1994; Santos, 2005), and second, to practical considerations of the research process and research design. 
When attempting to answer these two questions, researchers need to be mindful of three core considerations. First, that there must be a degree of consistency between ontological beliefs and an epistemological standpoint (Guba and Lincoln, 1998). In other words, our beliefs about the nature of the external world influences how we as researchers can or cannot gain knowledge about it. Second, that ontological and epistemological understandings necessarily dictate the means through which inference, the attribution of causality, and extrapolation can be practiced (Danermark et al, 2002; Steinmetz, 1998). In other words, that our beliefs about the relationship between a researcher and the external world determines how we generate our findings, how we ascribe causality, and to whom and to where we can reasonably apply our findings. And third, that a methodology must form a web that links the epistemological question (of how we can or cannot gain knowledge about the external world) to the choice, combination, and sequence, of research methods (Guba and Lincoln, 1998).

This paper illustrates how these three core considerations can be incorporated in micro-level research concerned with how individuals and households make a living - in other words, livelihoods research. It argues that the methodology of Burawoy's extended case method (ECM) and ontological/epistemological stance of critical realism provides a basis on which to conduct reflexive inductive livelihoods research, which can be referred to as an extended livelihoods approach.

The paper is divided into five sections. As an extended livelihoods approach necessarily needs to take a cross-disciplinary perspective, the first section briefly discusses crossdisciplinary research in development studies. The second section outlines Burawoy's (1998) methodological approach to ethnographic sociology. Whilst this extended case method (ECM) has been influential in sociology (Burawoy 1991, 2000), the approach does not appear to be used within development studies, despite being applicable and apposite. The third section discusses which ontological beliefs and epistemological standpoints might be consistent with such a methodology. It does so through discussing the tenets of the most common epistemological standpoints in social science: positivism and social constructivism. ${ }^{1}$ As the ECM is incommensurate with both of these stances, the section suggests that critical

\footnotetext{
${ }^{1}$ Parts of this section have been published as Prowse,M. (2007) 'Aid effectiveness: the role of qualitative research in impact evaluation' ODI Background Note, December 2007, Overseas Development Institute, London, UK.
} 
realism provides a solid ontological/epistemological basis for extended livelihoods research. The fourth section discusses the origins and characteristics of livelihoods research and frameworks. It suggests that Ellis's rural livelihoods approach provides a good conceptual and heuristic tool for extended livelihoods research. The fifth section briefly discusses research methods, and offers a menu of research tools that can be sequenced and iterated in light of particular research questions.

The paper concludes by arguing that extensive primary fieldwork - required by the first two dimensions of the ECM - requires sensitivity, reflexivity, application and an on-going dialogue between researchers and social actors.

\section{Cross-disciplinary research}

Due to the rigidities imposed by single discipline studies, in which the depth of analysis can lead to a loss of context, the value of cross-disciplinary research has come to the fore in development studies (Hulme and Toye, 2006; White 2002, Harriss 2002). ${ }^{2}$ The case for cross-disciplinary research in development studies makes intuitive sense. The discipline can be understood as an attempt to understand the uneven and inequitable outcomes from the deepening of capitalism (immanent development), and the efficacy of intentional interventions (imminent development) in ameliorating the faults associated with this 'progress' (Cowen and Shenton, 1996). In this respect, development is a process of fundamental social change, not simple economic upgrading. Understanding this process necessarily requires insights from numerous academic disciplines (including economics, sociology, political science, geography, demography) and the benefits that different types of research methods can bring. In this respect, cross-disciplinary research moves beyond the simplistic notion that quantitative data provides hard, rigorous, objective, and scientific data, whilst qualitative data is soft, anecdotal, subjective, and descriptive (Harriss, 2002; Hulme and Toye, 2006; White, 2002). ${ }^{3}$

One example of where cross-disciplinary research and mixed methods have entered the mainstream development discourse, and informed development policy, is through livelihoods

\footnotetext{
${ }^{2}$ Cross-disciplinary research tends to take one of two forms: firstly, multi-disciplinary research where disciplinary specialists collaborate to highlight different angles on a particular research phenomenon, or secondly, inter-disciplinary research where an individual or groups of researchers, in an explicit and sustained manner, integrate different disciplines during the research process (Kanbur 2001).

${ }^{3}$ White (2008) offers an excellent example of how to integrate insights from different disciplines and research methods.
} 
research (loosely defined here as micro-level studies that chart and understand how individuals, households and communities make a living). Indeed, Murray (2000) argues that for livelihoods research to be successful, and for it to be effectively linked to policy, it must include: first, a sequence and combination of quantitative and qualitative research methods; and second, an explicit and sustained analytical tension between macro-, meso- and microlevels (see Murray 2000, 2002). We return to livelihoods research in section four. Now we turn to Burawoy's ECM, which can provide a methodology for an extended livelihoods approach.

\section{The extended case method}

The ECM is an approach to conducting ethnographic sociological research (Burawoy 1991, $1998,2000,2003)$. Ethnography at the simplest level can be described as the practice of direct observation of social phenomena by an individual participant (see Vidich and Lyman 2000: 39). A thicker definition of the term is provided by Willis and Trondman:

'Ethnography is a family of methods involving direct and sustained social contact with agents, and of richly writing up the encounter, respecting, recording, representing at least partly in its own terms, the irreducibility of human experience. Ethnography is the disciplined and deliberate witness-cum-recording of human events.' (Willis and Trondman, 2000: 5)

The ECM is one member of this family of methods. This particular style of participant observation takes dialogue and reflexivity as its main defining features, and contrasts its approach with the foundations and practices of positivist social science. It has been codified and formalised by Burawoy (1998), and is 'extended' in four dimensions. Each dimension is guided by a reflexive principle. These reflexive principles minimise the power effects inherent in researching and writing about the social world. The four dimensions, their attendant reflexive principles, and the power effects which reflexivity militates against, are now summarised in turn.

The first dimension is the movement of the observer to participant, with the researcher leaving their own social world and entering the social world of participants. In contrast to positivism that attempts to insulate the effects of the researcher's intervention on the social context, the ECM recognises that all interventions create disturbances. However, through being sensitive and reflexive about these disturbances the ECM suggests that such disturbances can be the basis for understanding some aspects of participant's social 
context. In other words, 'interventions create perturbations that are not noise to be expurgated but music to be appreciated, transmitting the hidden secrets of the participants' world' (Burawoy, 1998: 14). This type of reflexive research recognises the power relations that are inherent within research relationships, and indeed within all social fields. These relations of domination are unavoidable, cannot be dissolved, and limit our understanding of the social world.

The second dimension of the ECM is that participant observation is extended through time and space - it is only through longitudinal immersion in a social world that ethnographers are able to link scenarios and circumstances, compare them with theory, and build up a picture of social processes. However, through aggregating social situations, and integrating multiple observations into social processes, researchers unavoidably make choices, thereby silencing particular experiences and voices. The ECM necessitates an awareness of the power of the researcher to privilege certain voices and exclude others.

The third dimension is to extend out from micro processes to macro forces. In a similar fashion to Murray (2002) and Long (2001), this necessitates linking observations and social processes to their historical development, and to both macro societal and international forces. This does not just mean showing the means through which structuration occurs (Giddens, 1984), but necessitates an understanding of how the global influences the local. The inherent danger with linking micro-level processes with macro-level forces is what Burawoy calls 'objectification' - giving macro forces primacy in determining social actions and practices (see Long 2001: 13). This is tempered by the explicit recognition of the capacity and innovation of social actors.

The fourth dimension is extending theory. Taking the perspective that theory never just emerges from data (for example, see Glaser and Strauss 1967), the ECM looks not to confirm theory, but to contest it. Throughout the research process, data and theory are juxtaposed, with tentative predictions investigated and assessed, and anomalies and unexpected results helping to reconstruct theory. This leads towards an evolving set of research hypotheses. Appropriate research tools are deployed to investigate phenomena, leading to the reconstruction of theory. Through an iterative dialogue, and the eventual presentation of research findings to research participants, data and theory are eventually brought together. However, in attempting to make the world comprehensible by reducing complexity to categories, the danger is that data is shoehorned into a theory, or theory is 
altered needlessly to incorporate superficial data. The two-way process of reconstructing theory necessitates that uncertain data and speculative theoretical postulations end up on the cutting room floor.

These are the fundamental tenets of the ECM, or what Burawoy (1998) refers to as reflexive social science. The ECM is an unusual approach to ethnography by current sociological and anthropological standards due to its approach to 'extroversion'. In contrast to limiting ethnographic analysis to the intensive study of a small locality, the ECM necessitates engagement with wider forces (Burawoy, 1991: 6). The ECM's focus on the role of global forces stems from early ethnographic approaches in sociology, and later ethnographic approaches in anthropology.

For Burawoy (2000), the early ethnography of the Chicago school, epitomised by the work of Thomas and Znaniecki (1927), is an example of where local-level ethnography is linked to global trends and patterns. Such ethnographic 'extroversion' was short lived, and Blumer's 'symbolic interactionism' led the Chicago school to the study of enclosed localities and institutions without reference to the wider world (see Hammersley, 2004). The increasingly myopic focus of Chicago school ethnography contrasts with the history of the ethnographic enterprise in anthropology. Whereas initial anthropological accounts focused on 'the small scale society - ahistorical, ethnographic and comparative' (Ferguson and Gupta, 1997: 6), the Manchester school of anthropology, stemming from the work of Gluckman (1941) and Wilson (1941), included global and macro forces in their analysis (see Van Donge, 1985; Werbner, 1984). In addition to such 'extroversion', and providing its name, the Manchester school made four further contributions to the development of the ECM.

First, that an incisive method of analysing social process is to focus on conflict and social drama: not only as these moments of tension highlight the underpinnings of the social world, but as conflict is an integral part of societal forms (Turner, 1957). Second, that to highlight the complexities of social responsibilities and animosities, the ethnographic account should focus on a small number of (often related) individuals or groups (Long, 1968). Third, that the focus on social process necessitates the study of practices as well as norms and discourse (Van Velson, 1964, 1967). And fourth, that a focus on discrepant cases can give a clear understanding of social process - in other words, that exceptions often prove the rule (ibid.). 
Burawoy (2000) argues that with the demise of the Manchester school (which was criticised inter alia for its implicitly colonial and conservative agenda - see Van Donge, 1985), the spirit of the ECM was picked up by Pierre Bourdieu. Burawoy (2000) goes as far as to argue that Bourdieu's concepts of social field and habitus can be found in the work of Epstein (1967) and Turner (1957), respectively. Whether this is the case or not, it is clear that the Manchester school provided the backbone (and the name) of what Burawoy (1998) transformed into the ECM. Moreover, Burawoy (1998) follows in the tradition of the Manchester school through arguing that both quantitative and qualitative research tools can be used within an ethnographic research project. However, using both sets of methods can be problematic. Quantitative and qualitative research methods are closely aligned with the epistemological standpoints of positivism and social constructivism, respectively, both of which are incompatible with the ECM.

\section{Positivism, social constructivism and critical realism}

Positivism transfers the methods of physical science into social science, and seeks to understand the social world by uncovering universal laws through the measurement of the 'constant conjunction of events' between two or more phenomena (Steinmetz, 1998). These universal laws are empirical generalisations which are seen to be (mainly) independent of time/space and are neutral and value free (Steinmetz, 1998).

Positivists discover empirical generalisations through setting up and testing hypotheses in a deductive manner, with non-falsified hypotheses being extrapolated to a wider range of cases (Danermark et al, 2002; Popper, 1992). Non-falsified hypotheses are accepted and extrapolated because positivists understand the social world as a closed system (Steinmetz and Chae, 2002). In this respect, positivism is a form of naturalism which believes in the unity of the natural and social sciences (Bhaskar, 1989), and hence attempts to replicate the requirements of physical science, such as prediction, closed experimentation, the separation of research findings from interpretation (Steinmetz and Chae, 2002).

Positivism's hypothetico-deductive explanatory model relies on Humes' model of causation where 'regularity conjunctions are both necessary and sufficient for attributions of causality' (Baert, 1998: 192). For positivists, the observation that two variables are strongly correlated is understood to signify a causal relationship (Danermark et al, 2002; Green and Hulme, 2005). Whilst in fact what positivists allege to be an explanation is just an observed 
statistical relation that does not necessarily refer to any generative causal mechanisms (Baert, 1998; Danermark et al, 2002). Moreover, the extent to which positivism moves unproblematically from ex post explanation to ex ante prediction is also seen as contentious (Baert, 1998).

Positivism is (usually) linked to an empiricist ontology. This states that nothing exists in the external world outside of observable phenomena and rejects the 'invocation of theoretical, abstract, and unobservable entities.' (Steinmetz, 2004: 357). For empiricists, causality occurs at the same level at which their effects are felt, the very same level that individuals can access and gain knowledge about (Steinmetz, 2004). Empiricists also believe that social mechanisms exist 'independently of the agents' conceptions of what they are doing in their activity' (Bhaskar, 1979: 48), and thus agents' interpretations are not of importance to social research (Steinmetz, 2004).

Burawoy (1998) outlines three main context effects that makes positivism incommensurate with the ECM. First, within positivist research interview effects are marginalised - where the influence of socio-biographical characteristics of the interviewer on the generation of data are negated due to an assumed objectivity. Second, positivist research ignores respondent effects - where the message received by the respondent may well be different from the message the interviewer intended to send. Both of these contextual effects relate to the same key point: humans do not act like molecules, we interpret the social world and act accordingly. Third, positivists' assumed closed system often ignores field effects: the political, social and economic climate and currents that permeate all social fields. Clearly, the ECM cannot be linked to a positivist worldview. However, the ECM is also incompatible with the other main standpoint in the social sciences - that of social constructivism.

Social constructivism is related to, but distinct from, the much older interpretive tradition in sociology. Based on the neo-Kantian distinction between the study of the social world and the natural world because the former is 'inherently meaningful' (Schwandt, 2000: 191), interpretive researchers are concerned with understanding the meanings that individuals ascribe to their surroundings, actions and practices. This is because individuals' subjectivities stimulate and are constitutive of conduct and action (Baert 1998). Interpretivists gain access to the realm of both discursive and tacit knowledge through participant observation, where gaining understanding of one action is predicated on a wider understanding of the full range of actions (Schwandt, 2000). 
Social constructivists are distinct from this interpretivist tradition, and take exception to the way 'the interpreter objectifies (i.e. stands over and against) that which is to be interpreted' (Schwandt, 2000: 194). Social constructivists posit that all types of knowledge are constructed within the cognitive framework and a priori theoretical concepts of an individual - therefore all understandings of the external world are not reflections of it, but are solely subjective interpretations (Schwandt, 2000). In this respect, social constructivists deny the existence of, and the possibility of accessing, objects in the external world (Steinmetz, 1998). Social constructivists integrate the ontological question of 'the nature and constitution of the external world' into the epistemological question of 'how can we gain knowledge about the external world', and deny the possibility of the latter. Social constructivists are sceptical of any truth claims about the external world. Moreover, they are dubious of the validity of any representation of the external world. In this respect, social constructivists are 'judgemental relativists' and do not offer any criteria by which to distinguish between different interpretations. Through folding ontological questions into the epistemological domain, social constructivists rely on anti-foundational relativist underpinnings. All knowledge is predicated on the values, ideas and judgements of the individual, and is locally and contextually defined (Danermark et al, 2002). The aggregation of values, ideas and beliefs, and their enactment in actions and conduct, lead to the creation of 'real' social processes - thereby discourses are not only the myths that we like to live by, but are key structuring principles in society (Santos, 2005).

Clearly, there are some deficiencies within this standpoint for development research seeking policy relevance. First, 'judgmental relativism' is a position that is incompatible with any type of policy intervention. Second, some social constructivists believe in the impossibility of social and cultural translation (Steinmetz, 2004). Based on the linguistics of Saussure, such researchers posit that as soon as one leaves one's own social community, social researchers are unable to 'translate' social actions and conduct. In combination with unequal power relationships between researchers and respondents, such translation difficulties contribute to social researchers imposing their own distinctions, understandings and beliefs on the social context, thereby reducing cultures and social practices to their own metric (Steinmetz, 2004). The implication of the 'lost in translation' argument is that social research outside of one's own community is untenable - a position at odds with much development research. 
These two epistemological standpoints underpin the majority of studies in the social sciences. Some argue that the axioms of the two approaches render them mutually exclusive (Denzin and Lincoln, 2000). Danermark et al (2002) refer to this dichotomy in the social sciences as the either/or approach. In contrast, critical realism is an attempt at a both/and approach to social research, and as we will see, one which is much more consistent with the tenets of the ECM.

Critical realism argues that social science should be able to make generalisable claims (and thus not fall into the 'judgemental relativism' of social constructivism), but that the subjectivities of individuals and the meanings imbued within action are central to understanding the external world (thus rejecting the 'concept independence' of positivism). And whilst acknowledging the role of agency in reproducing societal structure (Giddens, 1984), critical realism strives to highlight societal structures. Instead of focussing on the epistemological question of 'how can we gain knowledge about the external world?' critical realists focus on a stratified and complex view of ontology (Steinmetz 2004), and ask 'what properties do societies and people possess that might make them possible objects for knowledge?' (Bhaskar, 1978: 13).

The starting point for critical realism is a belief in three ontological domains - the empirical, the actual, and the real (Bhaskar, 1978; Danermark et al, 2002). The empirical domain is that which human experiences are limited to, and in which our research 'data' is generated. Our experience of this domain is necessarily filtered by our socio-biographical characteristics and mediated by our conceptual beliefs. ${ }^{4}$ The second ontological domain is the actual. This includes the empirical domain, but also includes those events that occur in the world but which nobody experiences. For example, if a tree falls in a forest but is not seen by someone, it occurs in the actual domain. The third ontological domain is the real. This includes both the empirical and the actual, and is the location for generative causal mechanisms that create concrete events in the external world. Danermark et al (2002) explain that when such 'mechanisms produce a factual event, it comes under the domain of the actual, whether we observe it or not. When such an event is experienced, it becomes an empirical fact' (Danermark et al, 2002: 199).

\footnotetext{
${ }^{4}$ In contrast to social constructivists, critical realists state that whilst 'data' is dependent on theory, it is not necessarily determined by it.
} 
Critical realism seeks explanation through analysing causal mechanisms via the effects they create in the empirical domain. ${ }^{5}$ But what methods and conceptual tools enable critical realists to theorise about casual mechanisms?

Critical realists argue that causal mechanisms can be understood through conceptual abstraction - isolating certain aspects of a phenomenon from wider forces that are acting on it. Abstraction is achieved through the repetitive iteration of abstractions with data generated in the empirical domain, leading to the refinement and re-structuring of theory. In addition to deduction and induction, such abstraction can be facilitated through two particular kinds of inference - retroduction and abduction. Retroduction involves abstracting from the empirical domain to the actual and real domains through theorising about what are the prerequisites for a phenomenon to exist (Danermark et al, 2002: 96). Two practices which are central to retroduction - counterfactual thinking, and the study of extreme cases where causal mechanisms are particularly apparent (the similarity with the ECM is particularly evident here). Abduction involves drawing upon analogies and metaphors (Baert 1998: 193), and often relies on the importation of concepts from different academic disciplines.

Critical realism is not a panacea for social researchers, but offers an epistemological and ontological route out of the staid and unproductive dualism of positivism and social constructivism. Moreover, and as we can see, it shares many characteristics with Burawoy's ECM. The approach is similar in intention, if not in form, to those of Giddens (1984) and Bourdieu (1990); the former due to the attempt to overcome the structure and agency dichotomy, the latter for the emphasis on theoretical sophistication built on empirical research (May 2001).

Critical realism does suffer from numerous shortcomings. First, whilst critical realism is based on strong philosophical underpinnings, it is relatively silent in terms of methodology (a gap which the ECM can fill), and research tools (to which we turn later). Critical realism argues that the choice of research methods should be defined in relation to the nature of the subject of study (Danermark et al, 2002), and advocates 'critical methodological pluralism' (see Olsen 2005). Second, Bhaskar's 'transcendental realism', on which critical realism is

\footnotetext{
${ }^{5}$ Generative causal mechanisms are not 'laws', but 'tendencies' which may or may not express actual effects at certain locations at particular points in time (Steinmetz 1998). In other words, the different domains of reality - real, actual, empirical - are rarely synchronised. For example, the real and actual domains are often at odds because the external world is an open system and is not insulated from wider forces. The implication of the social realm being an open system is that falsification is rejected as a method of inference.
} 
based, is a form of naturalism that believes in the unity of the physical and natural sciences. The inflection of naturalism, and the holistic approach to inference methods (where deduction is not rejected outright) and research tools (such as surveys), leads social constructivists to reject critical realism as a form of post-positivism (a harsh criticism in their eyes) (see Denzin and Lincoln, 2000; Denzin, 2004).

As is apparent from the discussion, there is a great degree of consistency between critical realism's attempt to 'to combine and reconcile ontological realism, epistemological relativism and judgemental rationality' (Archer et al, 1998: xi), and the axioms of the ECM. The similarities between the ECM and critical realism can be summarised as:

- Ontological realism - that it is possible to gain knowledge of the external world.

- Epistemological relativism - that all knowledge is predicated on a priori theoretical sensitisation. However, knowledge is theory-dependent not theorydetermined, empirical work is therefore valid, not as a representation of the truth, but as an improvement of theory.

- Judgemental rationalism - logic dictates the criteria by which theories can be judged.

- Whilst acknowledging the centrality of agency, the primary focus is on societal structures

- Causal mechanisms are not laws that can be uncritically extrapolated, but should be seen as 'tendencies' which are time and space specific.

- Generative causal mechanisms are most obvious during moments of conflict and drama, and within discrepant cases.
- Theory and data are iterated constantly to redefine research questions and hypotheses.

- Dialogue between researchers and participants and reflexivity are key defining principles.

- Within empirical work, the nature of the subject determines the methods - an adherence to critical methodological pluralism.

- Focus is on the improvement of theory

- Recognition of inherent power effects within social research.

- Focus on practices as well as meanings, norms and values.

Both the ECM and critical realism advocate that the nature of research questions should define research methods: a position that corresponds closely to the emphasis on crossdisciplinary research in development studies. Before we outline a menu of research methods 
that can be iterated to inform an extended livelihoods approach, we firstly turn to the origins and characteristics of livelihoods research and frameworks.

\section{Livelihoods research and frameworks}

Up until the early 1970s it was assumed that individuals in developing countries not employed in the advanced capitalist sector were farmers or fishermen languishing in a backward, non-capitalist sector. This view of the economy was shared by both modernisation and marxist theories of development. The modernisation theorists' perspective (Huntingdon, 1968; Parsons, 1964) stemmed in part from the Lewis model of structural change which saw the reallocation of labour from the 'backward' to 'modern' sector as the route to employment creation and economic growth. ${ }^{6}$ Separating the economy into discrete segments obfuscated the connections between rural and urban spheres, and the livelihood strategies between these areas.

From an orthodox Marxist perspective (relatively popular at the time), rural dwellers were seen as leading a primarily agrarian existence, and peasants would be subject to the inexorable process of proletarianisation. Successful peasant production or social movements were seen as obstacles to the formation of this 'class' (O'Laughlin, 2002), and informal ways of making a living were seen as a device for depressing formal wages (Allen 1998, Francis, 2000). Such a teleological understanding of social change 'robbed African peasants and workers of agency, their distinctive histories and their cultural identity' (O'Laughlin, 2002: 513).

Such dualistic and teleological theories of economic activity and social change were challenged by Hart's (1973) analysis of urban migrants in Accra. This showed that instead of being underemployed, members of the urban sub-proletariat (as they were described then) managed multiple economic activities and income streams not recognised by the state (Hart quoted in Allen, 1998: 357). Hart termed this the 'informal sector', a term quickly picked up by the International Labour Organisation, and which is now part of the development lexicon.

\footnotetext{
${ }^{6}$ Further classical theories of structural change (Chenery et al, 1986; Kuznets, 1966) also divided the economy into discrete sectors - urban/industrial vs. rural/agricultural - and posited that through economies of scale, the division of labour, and occupational specialisation, the urban sphere can transform the economy (Ellis 1998; Start 2001).
} 
Hart's work shows the ability of micro-level research to understand ways of making a living not acknowledged by mainstream development policymakers (Francis, 2000). ${ }^{7}$

Despite the popularity of livelihoods research in the past decade, such approaches are not linked to Hart's (1973) 'discovery' of the informal sector. Instead, livelihoods research is linked to the 'New Poverty Agenda' of the 1990s, which recognised the deficiencies of a solely income-based measurement of poverty. Using the experience of rapid East Asian industrialisation, and echoing earlier 'Basic Needs' approaches to development (Stewart, 1985; Streeten et al, 1982), the 1990s saw an increasing acceptance of health and education within a multi-dimensional view of poverty (World Bank, 2000). Four further influences from the 1980s fed into this expanded conception of poverty (Maxwell, 1999): Sen's work on entitlements, capabilities and functionings (see Sen, 1981; Dreze and Sen, 1991); Chambers's (1989) incorporation of isolation, powerlessness, and vulnerability into his conception of poverty; the Brundtland Commission's report on 'sustainable development' (see Redclift, 1987); and a renewed interest in vulnerability and coping strategies (de Waal, 1989). Chambers and Conway (1992) brought these disparate intellectual trends together, and proposed a Sustainable Rural Livelihoods (SRL) framework. ${ }^{8}$ This framework was expanded by DfID (2000) and became a popular tool within development studies, and development policy and planning. The SRL approach defined a livelihood as:

'The capabilities, assets (including both material and social resources) and activities required for a means of living. A livelihood is sustainable when it can cope with and recover from stresses and shocks and maintain or enhance its capabilities and assets both now and in the future, while not undermining the natural resource base' (DfID 2000, p.3).

The SRL framework for understanding how individuals and households make a living consists of four elements: a vulnerability context, an asset pentagon, transforming structures and processes, and livelihood strategies (illustrated in Figure 1).

\section{Figure 1 - DFID's Sustainable Rural Livelihoods Framework}

\footnotetext{
7 Similar inductive sociological research has played an important role recognising how multiple livelihoods often straddle urban and rural spheres (see Berry 1993, Tiffen et al 1994, Francis 2000), the importance of household developmental cycles in trajectories of accumulation (Murray 1987), and thirdly, the importance of the intra-household distribution of resources and labour (Whitehead 1990, Murray 1981, Mackintosh 1989, Crehan 1985, Moore and Vaughan 1994).

${ }^{8}$ Reflecting the strong environmental agenda at this time, Chambers and Conway (1992) placed a strong emphasis on the environmental sustainability of livelihoods, in additional to their stability and security (see Toner 2003, Rakodi 2002).
} 


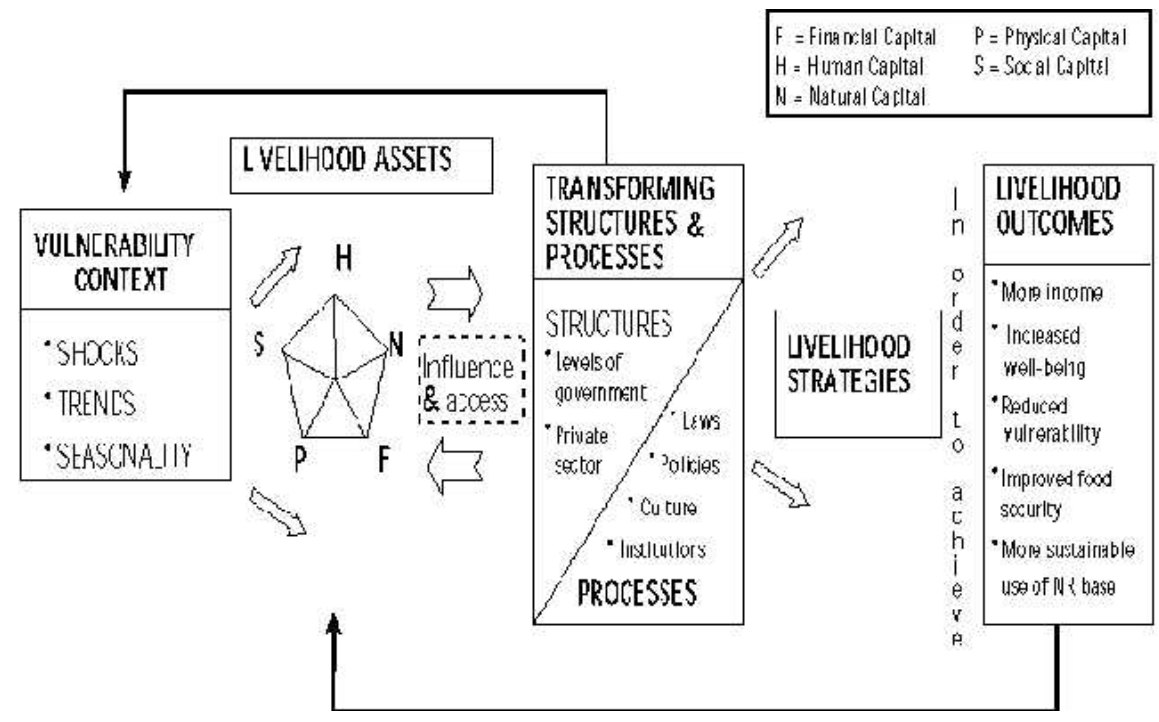

Source: Carney (1999).

The framework shows that the four inter-related elements should contribute to improved livelihood outcomes - increased well-being, more income, reduced vulnerability, improved food security, and a more sustainable use of the natural resource base (see Ashley and Carney, 1999; Carney et al, 1999; DfID 2000).

The SRL approach brought numerous benefits to research and policy: the dynamism of analysis, the realism of cross-sectoral analysis, the focus on people's strengths, and the link between macro and micro levels (Carney 1999). The framework encouraged a more peopleorientated approach to policy (DfID, 2000), and provided a common language for different sectors and academic disciplines (Bryceson, 1999). Moreover, the flexible and malleable nature of the SRL framework distinguished it from blueprint-orientated development approaches (DfID, 2000). ${ }^{9}$

But the SRL approach was not without fault, and four broad criticisms have been levelled at the terminology and structure of the framework. First, that the SRL approach has an undertheorised and implicitly unitary model of the household, instead of utilising a model of cooperative conflict (Rakodi, 2002). Second, that the SRL approach has an overly optimistic assumption that individuals and households are able to strategise as opposed to cope (Allen, 1998; Ellis, 2000; Rakodi, 2002; Toner, 2003; Wood and Solway 2000). Third, that

\footnotetext{
${ }^{9}$ Within DfID the SRL approach has been used in project and programme design; review, monitoring and evaluation work; and sectoral analysis (see Carney et al 1999, Hussein 2002).
} 
the SRL approach contains an under-emphasised and limited understanding of a 'vulnerability' context (Moser, 1998; Murray, 2000; Wood and Solway, 2000). Lastly, that the term 'sustainable' is too ambiguous (Murray 2000, 2002) and should be divided into livelihood 'security' and livelihood 'sustainability' (Rakodi 2002).

Three further criticisms focused on the conceptualisation of assets. Firstly, that assets in the SRL approach are not directly comparable (Beall, 2002; Maqueen, 2001; Pretty, 1999; Toner, 2003). Second, that the term social capital is of no analytical value as it is conceptualised in the SRL approach, and needs to be comprehensively disaggregated (Harriss and de Renzio, 1997; Woolcock 2001). Third, that the term social capital is too optimistic as it ignores processes of dependency (patron-client relations) and social exclusion (Wood, 2003; Beall, 2002; Thin, 2000).

Despite such criticisms, the SRL framework was used and expanded by NGOs, research establishments, and donors, and entered mainstream UK development discourse (Ashley and Carney, 1999). ${ }^{10}$ However, applying such frameworks in practice proved difficult. Donors and NGOs found it extremely difficult to operationalise: attempts to apply the entire framework overwhelmed staff, leading to concerns that livelihoods analysis became an end in itself, without contributing to evidence-based policy (Drinkwater and Rusinow, 1999; DfID 2001; Hussein 2002).

In the last few years, the SRL framework has slipped off the development radar: livelihoods frameworks are now seen as being unwieldy and unfashionable (perhaps a symptom of the breadth/depth trade off that Bernstein (2005) refers to). But it is important that we do not throw the baby out with the bathwater, for, as we have seen in the case of Hart, livelihoods research can highlight ways of making a living not appreciated in policy circles. Considering the reach and penetration of globalisation, the challenge of climate change, and the restructuring of the global economy wrought by the rise of China and India, livelihoods research is as vital as ever in understanding how individuals construct a living through combining activities and straddling spaces. In contrast to DfID's SRL framework, this paper

\footnotetext{
${ }^{10}$ CARE, UNDP, Oxfam, and Save the Children all developed types of livelihoods framework, and 'livelihoods analysis' was incorporated into the work of the FAO, IFAD and SIDA (see Hussein, 2002; Carney et al 1999). Many livelihoods frameworks differ substantially from the SRL approach; for example, CARE currently use a Household Livelihood Security model which attempts to incorporate a rights-based approach (see Conticini 2004).
} 
argues that Ellis's (2000) rural livelihoods framework offers a good basis for an extended livelihoods research. Ellis (2000) contends that a livelihood comprises:

'The assets (natural, physical, human, financial and social capital), the activities, and the access to these (mediated by institutions and social relations) that together determine the living gained by the individual or household' (p.10).

Ellis divides the study of livelihoods into six related components, and starts with an individual's or household's assets. These contribute to livelihood strategies, within a vulnerability context of trends and shocks, and through the mediating processes of social relations, institutions, and organisations (see Figure 2). ${ }^{11}$

\section{Figure 2 - Ellis's framework for micro policy analysis of rural livelihoods}

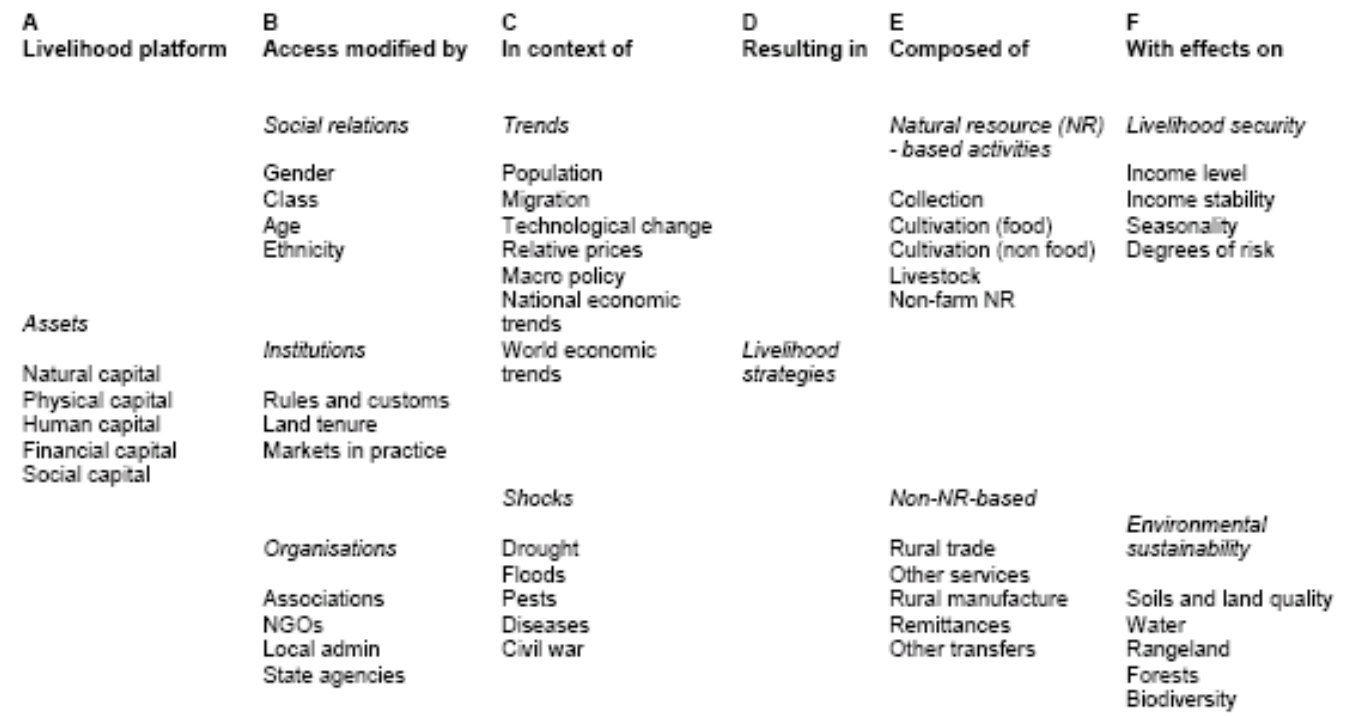

Source: Ellis (2000).

Despite the apparent similarity with DfID's SRL approach, Ellis makes a number of important distinctions. First, in terms of livelihood activities and outcomes, Ellis's differentiates between natural-resource-based activities and non-natural-resource-based activities, and splits livelihood outcomes into livelihood security and environmental sustainability (thus overcoming some of the criticisms of the SRL framework outlined above).

\footnotetext{
${ }^{11}$ The term 'livelihood strategy' overemphasises the ability of individuals/households to choose and select activities to make a living (dependent on their endowments), and negates the significance of the opportunities available to the individual/household (see Rakodi 2002, Toner 2003, Wood and Solway 2000). In using the term 'livelihood strategy' this thesis acknowledges that households are, due to a situation of duress, frequently constrained in their ability to strategise.
} 
Second, Ellis's alternative conceptualisation of mediating processes includes two important distinctions (both of which make his approach suitable for extended livelihoods research). First, in addition to the importance of institutions and organisations in understanding livelihoods, Ellis emphasises social characteristics such as gender, class, age and ethnicity, which the SRL marginalises within its conceptualisation of the 'Transforming Structures and Processes' (DFID, 2000).

The second important distinction is Ellis' attention to 'markets in practice', as opposed to an assumed scenario of market clearing at optimally efficient prices and contract enforcement. This is significant for it suggests that the structure and social organisation of markets must be researched (for example, through value chain analysis) and not assumed.

By pinning the origins of livelihoods research to Hart (and studies that followed a similar inductive livelihoods approach), and through using Ellis's livelihoods framework as a basis, we can show the importance of not abstracting economic activity from the sets of social practices, relations, obligations and histories in which they are located (see Bourdieu, 1990; Dilley, 1992; Granovetter, 1985; Long 2001; Polanyi, 2001; Van Donge, 1993). Such an approach follows in the actor-orientated approach to development research, which understands that whilst the agency and capabilities of individuals are important, these are 'bounded not only by structural constraints imposed by geography or demography, but preconditioned (a better term is probably embedded), as it were, by the available historical repertoire' (Noteboom, 2003 quoted in de Haan and Zoomers, 2005: 42). We now turn to the types of research methods that can be included in an extended livelihoods approach.

\section{Sequence of Research Methods}

Instead of using the terms quantitative and qualitative, Kanbur (2001) highlights how social research methods sit at some point along five broad continua:

1. Type of Information on Population: Non-Numerical to Numerical.

2. Type of Population Coverage: Specific to General.

3. Type of Population Involvement: Active to Passive.

4. Type of Inference Methodology: Inductive to Deductive.

5. Type of Value Framework: Multi-dimensional value vs. money-metric value.

In this respect, different types of research methods provide different types of data, and are therefore good at answering particular kinds of research questions. For example, numerical 
methods are good at answering 'what?' questions, whilst non-numerical methods are good at answering 'how?' and 'why?' questions (Woodhouse, 1998). This means that numerical methods, such as surveys, are good at capturing states or conditions (Ellis, 2000), whilst non-numerical methods are good at capturing processes (Murray, 2002). However, as the contextual benefits of qualitative research strive towards depth of understanding, this is usually only within a small locality. One of the major strengths of the non-contextual style of quantitative research is the breadth of coverage (see Chambers, 2001). The challenge, therefore, is to integrate quant and qual research methods in a way which captures depth of understanding and breadth of coverage, whilst being rigorous and reliable. Booth (2001) and Rao (2001) distinguish between different methods of integrating survey-based and contextual research methods. They highlight four different types of combinations:

1. Parallel - Where the research methods are conducting separately and both inform the findings and outputs of the research.

2. Linkage - Where contextual investigations, such as qualitative interviews, are a subcomponent of a sample survey, with the interviews fitted to survey sampling frames.

3. Convergence - Where contextual methods take on properties normally associated with surveys (i.e. random sampling).

4. Triangulation - Where different data sources, both between and within the two main methodological traditions, are sequenced and combined within the research design. There are two versions: (a) Classical - where contextual methods are used to generate a hypothesis which is then tested rigorously with quantitative statistical analysis; (b) Bayesian - methods are integrated in an iterative and dialogic fashion.

Following from the tenets of the ECM and critical realism described above, the combination of research methods most suited to inductive livelihoods research is the Bayesian approach to the triangulation of quantitative and qualitative methods where methods are integrated in an iterative and dialogic fashion. Through combining methods in this manner we move away from the risk of data mining, where data is fitted to a theory through statistical manipulation, and towards the analysis of data (White, 2002). Doing so gives a more grounded indication of causality than the speculation can accompany regression analysis of secondary datasets (Green and Hulme, 2005; White, 2008).

Table 1 shows a wide spectrum of research methods that could be utilised within extended livelihoods research. The methods are not clustered into quantitative or qualitative approaches, but instead loosely follow a sequence that was utilised within my PhD research. 
This matrix offers a tentative location for each of the research methods within each of the five continua outlined above (although, of course, particular research questions may require a different emphasis). 
Table 1 - Types of Research Method

\begin{tabular}{|c|c|c|c|c|c|c|}
\hline Broad style of research & $\begin{array}{l}\text { 'Type' of research } \\
\text { method }\end{array}$ & $\begin{array}{l}\text { Information } \\
\text { on population }\end{array}$ & $\begin{array}{l}\text { Population } \\
\text { coverage }\end{array}$ & $\begin{array}{l}\text { Population } \\
\text { involvement }\end{array}$ & $\begin{array}{l}\text { Inference } \\
\text { methodology }\end{array}$ & $\begin{array}{l}\text { Value } \\
\text { framework }\end{array}$ \\
\hline Literature review & Discourse analysis & Both & Mainly general & Passive & Inductive & - \\
\hline Institutional research & $\begin{array}{l}\text { Discourse analysis, } \\
\text { semi-structured } \\
\text { interviews }\end{array}$ & Both & Specific & Passive & Inductive & - \\
\hline Spatial analysis of datasets & Quantitative & Numeric & General & Passive & Deductive & - \\
\hline Focus group discussions & $\begin{array}{l}\text { Rapid Rural } \\
\text { Appraisal }\end{array}$ & Non-numerical & Specific & Active & Inductive & Multi-dimensional \\
\hline Semi-structured interviews & $\begin{array}{l}\text { Semi-structured } \\
\text { interviews }\end{array}$ & Both & Specific & Active & Inductive & Multi-dimensional \\
\hline Piloting household survey & Survey & Both & Specific & Active & Inductive & Multi-dimensional \\
\hline Household survey & Survey & Both & Specific & Passive & Deductive & Multi-dimensional \\
\hline Ethnography & $\begin{array}{l}\text { Participant } \\
\text { observation }\end{array}$ & Non-numerical & Specific & Passive & Inductive & Multi-dimensional \\
\hline Life history interviews & $\begin{array}{l}\text { Life history } \\
\text { interviews }\end{array}$ & Both & Specific & Active & Deductive & Multi-dimensional \\
\hline Genealogies & Family histories & Non-numerical & Specific & Active & Inductive & - \\
\hline $\begin{array}{l}\text { Presentation of findings to focus } \\
\text { groups and institutions }\end{array}$ & Focus group & Non-numerical & Specific & Active & Inductive & - \\
\hline
\end{tabular}




\section{Conclusion}

This paper has sketched out an ontological/epistemological basis and methodological approach for reflexive inductive livelihoods research that overcomes the unproductive social science dualism of positivism and social constructivism. The paper has suggested a conceptual framework and a menu of research methods that can be used within such microlevel research.

As is evident from the first two dimensions of the ECM - the movement of the observer to participant, and that participant observation is extended through time and space - this paper advocates substantial primary fieldwork. Within some of the social sciences (especially geography and anthropology) fieldwork used to be seen as a rite of passage - the process through which individuals pass to become part of the discipline. This led to remote and rural locations being seen as more 'real' fieldwork locations (Ferguson and Gupta, 1997). In this respect the 'fieldwork' tradition in these two disciplines has historically been imbued with 'Victorian-era expectations that personal growth (of implicitly masculine sort) could be affected through pilgrimages to unfamiliar places' (Kuclick quoted in Ferguson and Gupta, 1997: 48). Whilst there is no doubt that fieldwork is a time of personal growth, it is not necessarily of the masculine explorer variety. As the ECM shows, fieldwork is a process which requires sensitivity, reflexivity, application, and on ongoing dialogue between the researcher and social actors.

Being sensitive to the ripples one is creating means moving away from participant observation - based on the supremacy of observation over participation where the researcher had to cultivate rapport not friendships, show compassion not sympathy, seek understanding not identification (Tedlock, 2000: 457) - towards the observation of participation. Here it is not the level of immersion that is important but the 'competence of introspection and ability to reflect on experience' (Ellen 1984; p.31). The question of whether the researcher can adequately listen and observe is reformulated into the question of whether the researcher can competently perform. In this sense, fieldwork is a time of personal growth for it is an intense educational experience. Learning how to perform competently in different social spheres necessitates sensitivity to your context, and an ability to respond accordingly: a researcher must wear many different hats at different times, as well as being able to build sincere and informative inter-personal relationships with a range of individuals differentiated by gender, race, ethnicity and class. 
To be able to engage competently with social actors (whether they are a government bureaucrat, a private sector manager, or a peasant) a researcher must be able to display an adequate understanding of their life-world and the discourses they use. In offices in cities, this might mean understanding the acronyms and buzzwords used by employees, locating political and strategic interests, and relating these to broader academic and theoretical arguments. In fields and on the shop floor it might mean understanding a different type of diction, learning about different social practices and conventions, and locating these within broader discourses and arguments (often formulated within elite spaces in urban areas). Moving between such spheres might bring into relief a tension between how policy conceptualises the life-world of social actors, and the interpretations and folk wisdom of social actors themselves. Such a tension is a good starting point for the iteration of theory and data, using the most appropriate tools from the full spectrum of research methods. 


\section{References}

Allen, T. (1998). 'Informal Sectors' To 'Real Economies': Changing Conceptions Of Africa's Hidden Livelihoods. Contemporary Politics 4(4): 357-73.

Archer, M. et al. (1998). Critical Realism : Essential Readings. London, New York : Routledge.

Ashley, C. and D. Carney (1999). Sustainable Livelihoods: Lessons From Early Experience. London: DfID.

Baert, P. (1998). Social Theory In The Twentieth Century. Cambridge : Polity Press.

Beall, J. (2002). Living In The Present, Investing In The Future - Housing Security Among The Poor. In Urban Livelihoods: A People-Centred Approach To Reducing Poverty. C. Rakodi and T. Lloyd-Jones. London : Earthscan Publications Ltd

Bernstein, H. (2005). Development Studies And The Marxists. In A Radical History Of Development Studies. U. Kothari (Ed). London : Zed Books.

Berry, S. S. (1993). No Condition Is Permanent : The Social Dynamics Of Agrarian Change In Sub-Saharan Africa. Madison, Wis. : University of Wisconsin Press.

Bhaskar, R. (1978). A Realist Theory Of Science. Hassocks : Harvester Press.

Bhaskar, R. (1979). Philosophy And The Human Sciences. Brighton : Harvester Press.

Bhaskar, R. (1989). The Possibility Of Naturalism : A Philosophical Critique Of The Contemporary Human Sciences. New York, London : Harvester Wheatsheaf.

Booth, D. (2001). Towards A Better Combination Of The Quantitative And The Qualitative. Q-Squared: A Commentary On Qualitative And Quantitative Poverty Appraisal. R. Kanbur (Ed), Cornell University Department of Applied Economics and Management Working Paper No. 105.

Bourdieu, P. (1990). The Logic Of Practice. Oxford : Basil Blackwell.

Bryceson, D. F. (1999). African Rural Labour, Income Diversification And Livelihood Approaches. Review Of African Political Economy 26(80): 171-190.

Bryceson, D. (2000). Rural Africa At The Crossroads: Livelihood Practices And Policies. Natural Resources Perspectives 52. London : Overseas Development Institute

Burawoy, M. (1991). Ethnography Unbound : Power And Resistance In The Modern Metropolis. Berkeley, Calif. ; University of California Press.

Burawoy, M. (1998). The Extended Case Method. Sociological Theory 16(1): 4-33.

Burawoy, M. (2000). Global Ethnography : Forces, Connections, And Imaginations In A Postmodern World. Berkeley, Calif. : University of California Press.

Burawoy, M. (2003). Revisits: An Outline Of A Theory Of Reflexive Ethnography. American Sociological Review 68(5): 645-679. 
Carney, D., (Ed) (1999). Sustainable Rural Livelihoods: What Contribution Can We Make? London : DfID.

Carney, D., M. Drinkwater, et al. (1999). Livelihoods Approaches Compared. London : DfID.

Chambers, R. (1989) 'Vulnerability, coping and policy' IDS Bulletin 20, No. 2. IDS, University of Sussex.

Chambers, R. (2001). Qualitative Approaches: Self Criticism And What Can Be Gained From Quantitative Approaches. In Q-squared: A commentary on Qualitative and Quantitative Poverty Appraisal. R. Kanbur (Ed), Cornell University Department of Applied Economics and Management Working Paper No. 105.

Chambers, R. and G. R. Conway (1992). Sustainable Rural Livelihoods: Practical Concepts For The 21st Century. Discussion Paper 296. Brighton, UK : Institute of Development Studies.

Chenery, H. B., S. Robinson, et al., (Eds). (1986). Industrialisation Growth: A Comparative Study. New York: Oxford University Press.

Conticini, A. (2005). We Are The Kings: The Children Of Dhaka's Streets. Manchester, University of Manchester, Ph.D.

Cowen, M. and R. W. Shenton (1996). Doctrines Of Development. London, New York : Routledge.

Crehan, K. (1985). Production And Gender In North-Western Zambia. In Food Systems And Central And Southern Africa. J. Pottier (Ed). London : School of Oriental and African Studies.

Danermark, B., M. Ekstrom, L.Jakobsen and J.C. Karlson (2002). Explaining Society : An Introduction To Critical Realism In The Social Sciences. London, New York : Routledge.

de Haan,L. and Zoomers,A. (2005) Exploring the Frontier of Livelihoods Research. Development and Change 36 (1) , 27-47

de Waal, A. (1989). Famine That Kills : Darfur, Sudan, 1984-1985. Oxford, New York: Clarendon Press, Oxford University Press.

Denzin, N. K. (2004). Explaining Society: Critical Realism In The Social Sciences.

Contemporary Sociology - a Journal of Reviews 33(2): 249-250.

Denzin,N. and S. Y. Lincoln (Eds). (1994) The Handbook Of Qualitative Research. LondonNew Delhi : Sage Publications Ltd.

Denzin, N. K. and Y. S. Lincoln (Eds) (2000). Handbook Of Qualitative Research. Thousand Oaks, Calif. ; London, Sage Publications.

DfID (2000). Sustainable Livelihoods - Current Thinking And Practice. London : Department for International Development.

Dilley, R., Ed. (1992). Contesting Markets: Analyses Of Ideology, Discourse And Practice. Edinburgh : Edinburgh University Press. 
Dreze,J. and Sen,A. (1991). Hunger and Public Action. Oxford, UK : OUP.

Drinkwater, M. and T. Rusinow (1999). Application Of CARE's Livelihoods Approach

Presentation for NRAC 1999. See http://www.livelihoods.org/info/nrac/care.pdf.

Ellen,R.F (1984). Ethnographic Research: A General guide to Conduct. London, UK : Academic Press.

Ellis, F. (1998). Household Strategies And Rural Livelihood Diversification. Journal of Development Studies 35(1): 1-38.

Ellis, F. (2000). Rural Livelihoods And Diversity In Developing Countries. Oxford, New York : Oxford University Press.

Epstein, A. L., (Ed) (1967). The Craft Of Social Anthropology. London : Tavistock.

Ferguson, J. and A. Gupta (1997). Anthropological Locations : Boundaries And Grounds Of A Field Science. Berkeley, Calif. : University of California Press.

Francis, E. (2000). Making A Living: Changing Livelihoods In Rural Africa. London : New York, Routledge.

Giddens, A. (1984). The Constitution Of Society; An Outline Of The Theory Of Structuration. Cambridge : Polity Press.

Glaser, B. G. and A. L. Strauss (1967). The Discovery Of Grounded Theory: Strategies For Qualitative Research. Hawthorne, N.Y. : Aldine de Gruyter.

Gluckman, M. (1941). Economy Of The Central Barotse Plain. Livingstone, Northern Rhodesia: The Rhodes-Livingstone Institute.

Granovetter, M. (1985). Economic-Action And Social-Structure - The Problem Of Embeddedness. American Journal of Sociology 91(3): 481-510.

Green, M. and D. Hulme (2005). From Correlates And Characteristics To Causes: Thinking About Poverty From A Chronic Poverty Perspective. World Development 33(6): 867-880.

Guba, E. G. and Y. S. Lincoln (1998). Competing Paradigms in Quantitative Research. In N. Denzin and S. Y. Lincoln (Eds). The Landscape Of Qualitative Research. London-New Delhi : Sage Publications Ltd.

Hammersley, M. (2004). Towards A Usable Past For Qualitative Research. International Journal of Social Research Methodology 7(1): 19-27.

Harriss, J. (2002). The Case For Cross-Disciplinary Approaches In International Development. World Development 30 (3): 487-496.

Harriss, J. and P. D. Renzio (1997). Missing Link Or Analytically Missing? The Concept Of Social Capital. Journal of International Development 9 (7): 919-937.

Hart, K. (1973). Informal Income Opportunities And Urban Employment In Ghana. Journal of Modern African Studies 11 (1) : 61-89.

Hulme, D. and J. Toye (2006). The Case For Cross-Disciplinary Social Science Research 
On Poverty, Inequality And Well-Being. Q-squared Working Paper No. 19. Toronto : Qsquared Research Centre, Centre For International Studies, University Of Toronto.

Huntington, S. (1968). Political Order In Changing Societies. New Haven, London : Yale University Press.

Hussein, K. (2002). Livelihoods Approaches Compared: A Multi-Agency Review of Current Practice. London : DfID.

Kanbur, R., (Ed) (2001). Q-Squared: A Commentary On Qualitative And Quantitative Poverty Appraisal, Cornell University Department of Applied Economics and Management Working Paper No. 105.

Kothari,U. (Ed) (2005). A Radical History Of Development Studies. London : Zed Books.

Kuznets, S. S. (1966). Modern Economic Growth: Rate, Structure And Spread. New Haven \& London : Yale University Press.

Long, N. (1968). Social Change And The Individual: A Study Of The Social And Religious Responses To Innovation In A Zambian Rural Community. Manchester : Published for the Institute for Social Research, University of Zambia, by Manchester University Press.

Long, N. (2001). Development Sociology: Actor Perspectives. London : Routledge.

Mackintosh, M. (1989). Gender, Class And Rural Transition : Agribusiness And The Food Crisis In Senegal. London : Zed Books.

Maqueen, D. (2001). Measurement Malaise_Is The SL Approach Inoperable? Kent, UK : Natural Resources Institute.

Maxwell, S. (1999). The Meaning And Measurement Of Poverty. ODI Poverty Briefing No. 3. London: Overseas Development Institute.

May, T. (2001). Social Research : Issues, Methods And Process. Buckingham : Open University Press.

Moore, H. L. and M. Vaughan (1994). Cutting Down Trees: Gender, Nutrition, And Agricultural Change In The Northern Province Of Zambia, 1890-1990. London : Currey.

Moser, C. O. N. (1998). The Asset Vulnerability Framework: Reassessing Urban Poverty Reduction Strategies. World Development 26(1): 1-20.

Murray, C. (1981). Families Divided: The Impact Of Migrant Labour In Lesotho. Cambridge : Cambridge University Press.

Murray, C. (1987). Class, Gender And The Household - The Developmental Cycle In Southern-Africa. Development and Change 18(2): 235-249.

Murray, C. (2000). Changing Livelihoods: The Free State, 1990s. African Studies 59(1).

Murray, C. (2002). Livelihoods Research: Transcending Boundaries Of Time And Space. Journal of Southern African Studies 28(3): 489-509.

O'Laughlin,B. (2002). Proletarianisation, Agency and Changing Rural Livelihoods: Forced 
Labour and Resistance in Colonial Mozambique. Journal of Southern African Studies, Volume 28, Number 3, September 2002.

Olsen, W. and J. Morgan (2005). A Critical Epistemology Of Analytical Statistics: Addressing The Sceptical Realist. Journal for the Theory of Social Behaviour 35(3): 255-284.

Parsons, T. (1964). Evolutionary Universals In Society. American Sociological Review 29.

Polanyi, K. (2001). The Great Transformation : The Political And Economic Origins Of Our Time. Boston, MA : Beacon Press.

Popper, K. R. S. (1992). The Logic Of Scientific Discovery. London : Routledge.

Pretty, J. (1999). Capital Assets And Natural Resource Improvements: Linkages And New Challenges, Essex : Centre for Environment and Society, University of Essex.

Punch, M. (1994). Politics And Ethics In Qualitative Research. In Handbook of Qualitative Research. N. Denzin and Y. Lincoln (Eds). London : Sage Publications.

Rakodi, C. (2002). A Livelihoods Approach. Conceptual Issues And Definitions. In Urban Livelihoods: A People-Centred Approach To Reducing Poverty. C. Rakodi and T. LloydJones (Eds). London : Earthscan Publications Ltd.

Rao, V. (2001). Potters And Slums: Two Qualitative/Quantitative Projects In India. In QSquared: A Commentary On Qualitative And Quantitative Poverty Appraisal. R. Kanbur (Ed), Cornell University Department of Applied Economics and Management Working Paper No. 105.

Redclift, M. (1987). Sustainable Development : Exploring The Contradictions. London : Methuen.

Santos, R. C. L. F. D. (2005). Development And Sustainability Of Information Systems For Public Budget Transparency: A Case Study From Brazil Using A New Institutional Approach. Manchester : University of Manchester. Ph.D.

Schwandt, T. A. (2000). Three Epistemological Stances For Qualitative Inquiry: Interpretivism, Hermeneutics, And Social Constructionism. In Handbook Of Qualitative Research. N. K. Denzin and Y. S. Lincoln (Eds). Thousand Oaks, Calif. : Sage Publications.

Sen,A. (1981) Poverty and Famines: an Essay on Entitlement and Deprivation. Oxford, UK : Clarendon Press.

Start, D. (2001). The Rise And Fall Of The Rural Non-Farm Economy: Poverty Impacts And Policy Options. Development Policy Review 19(4): 491-505.

Steinmetz, G. (1998). Critical Realism And Historical Sociology. A Review Article. Comparative Studies in Society and History 40(1): 170-186.

Steinmetz, G. (2004). Odious Comparisons: Incommensurability, The Case Study, And 'Small N's' In Sociology. Sociological Theory 22(3): 371-400.

Steinmetz, G. and O. B. Chae (2002). Sociology In An Era Of Fragmentation: From The Sociology Of Knowledge To The Philosophy Of Science And Back Again. Sociological Quarterly 43 (Winter): p.111-37. 
Stewart, F. (1985). Planning To Meet Basic Needs. London : Macmillan.

Streeten, P. with Shahid Javed Burki, Mahbub ul Haq, Norman Hicks and Frances Stewart (1982). First Things First : Meeting Basic Human Needs In The Developing Countries. New York : Published for the World Bank by Oxford University Press.

Tedlock,B. (2000). Ethnography and Ethnographic Representation. In Denzin,N.K. and Lincoln,Y.S. (eds.) (2000) Handbook of Qualitative Research. London, UK : SAGE.

Thin, N. (2000). Characteristics Of DFID-Funded Projects. SCOPE paper No. 12. London : DfID Social Development Department.

Thomas, W. I. and F. W. Znaniecki (1927). The Polish Peasant In Europe And America. New York : A. A. Knopf.

Tiffen, M., M. Mortimore, et al. (1994). Environment, Population Growth And Productivity In Kenya : A Case Study Of Machakos District. London : International Institute for Environment and Development.

Toner, A. L. (2003). Knowing Poverty: Critical Reflections On Participatory Research And Policy. Journal of Development Studies 40(1): 183-185.

Turner, V. W. (1957). Schism And Continuity In An African Society: A Study Of Ndembu Village Life. Manchester : Published on behalf of the Rhodes-Livingstone Institute by Manchester University Press.

van Donge, J. K. (1985). Understanding Rural Zambia Today: The Relevance Of The Rhodes-Livingstone Institute. Africa 55 (1) : 60-76.

van Donge, J. K. (1993). Trapped In Decline. A Sociological Analysis Of Economic Life In Mgeta, Uluguru Mountains Tanzania. Wageningen: Landbouwuniversiteit Wageningen.

van Velsen, J. (1964). The Politics Of Kinship: A Study In Social Manipulation Among The Lakeside Tonga Of Nyasaland. Manchester : Manchester University Press.

van Velsen, J. (1967). The Extended-Case Method And Situational Analysis. In The Craft Of Social Anthropology. A. L. Epstein (Ed). London : Tavistock.

Vidich, A. J. and S. M. Lyman (2000). Qualitative Methods: Their History In Sociology And Anthropology. In Handbook of Qualitative Research. N. K. Denzin and Y. S. Lincoln (Eds). London : SAGE.

Werbner, R. (1984). The Manchester School In South-Central Africa Annual Review of Anthropology 13.

White, H. (2002). Combining quantitative and qualitative approaches in poverty analysis. World Development. 30(3), 511-522.

White, H. (2008) Of Probits and Participation: The Use of Mixed Methods in Quantitative Impact Evaluation. Nonie Working Paper No. 6. January 2008. Network of Networks Impact Evaluation Initiative, World Bank.

Whitehead, A. (1990). Food Crisis and Gender Conflict in the African Countryside. In The 
Food Question : Profits Versus People? H. Bernstein (Ed). London : Earthscan.

Willis, P. and M. Trondman (2000). Manifesto For Ethnography. Ethnography 1(1): 5-16.

Wilson, G. (1941). An Essay On The Economics Of Detribalization In Northern

Rhodesia...By Godfrey Wilson. Livingstone, Northern Rhodesia : The Rhodes-Livingstone institute.

Wood, G. (2003). Staying Secure, Staying Poor: The 'Faustian Bargain'. World Development 31(3): 455-471.

Wood, G. and S. Solway (2000). Securing Livelihoods In Dhaka Slums. Journal of International Development 12: 669-688.

Woodhouse, P. (1998). People as Informants. In Finding Out Fast: Investigative Skills For Policy And Development. A. Thomas, J. Chataway and M. Wuyts (Eds). London : Oxford University Press.

Woolcock, M. (2001). The Place Of Social Capital In Understanding Social And Economic Outcomes. Canadian Journal of Policy Research 2(1).

World Bank (2000). World Development Report 2000/1. Washington D.C. : World Bank. 


\section{Executive Director}

Professor Tony Addison

\section{Research Director}

Professor Michael Woolcock

Associate Director

Professor David Hulme

\section{Contact:}

Brooks World Poverty Institute

The University of Manchester

Humanities Bridgeford Street

Building

Oxford Road

Manchester

M13 9PL

United Kingdom

\section{Email: bwpi@manchester.ac.uk}

www.manchester.ac.uk/bwpi
The Brooks World Poverty Institute (BWPI) creates and shares knowledge to help end global poverty.

BWPI is multidisciplinary, researching poverty in both the rich and poor worlds.

Our aim is to better understand why people are poor, what keeps them trapped in poverty and how they can be helped - drawing upon the very best international practice in research and policy making.

The Brooks World Poverty Institute is chaired by Nobel Laureate, Professor Joseph E. Stiglitz. 